\title{
TESTING DEFORMATION AND COMPRESSIVE STRENGTH OF THE FROZEN FINE-GRAINED SOILS WITH CHANGED POROSITY AND DENSITY
}

\author{
V. LEMENKOV a, Polina LEMENKOVA ${ }^{\text {b* }}$ \\ a Geoprojectsurvey LLC, Moscow, Russia, E-mail: wasiliy.lemenkov@ gmail.com \\ $b^{*}$ Schmidt Institute of Physics of the Earth, RAS. Department of Natural Disasters, Anthropogenic Hazards and Seismicity of the \\ Earth. Laboratory of Regional Geophysics and Natural Disasters. Moscow, Russia, E-mail: pauline.lemenkova@gmail.com
}

Received: 30.08.021 / Accepted: 05.09.2021 / Revised: 01.10.2021 / Available online: 15.12.2021

DOI: 10.2478/jaes-2021-0015

KEY WORDS: Frozen soils, Frost heave, Deformation, Compressive strength, Soil porosity, Soil density, Clay, Loam.

\begin{abstract}
:
Current paper focuses on the laboratory experiments performed wit aim to test the deformation in the frozen loam soil specimens. Loam frozen soils are subject to the external effects, such as climate and environmental impacts including temperature changes. Soil heave is one of the key features restraining possible area development: construction of buildings, roads and railways. Necessarily, this requires the improvements of methods of the assessment of heave. This research evaluated the compressive strength and deformation in several specimens of the frozen soil. The approach included varying load and physical properties of soil specimens: porosity, pore filling, moisture, density of soil particles and dry soil density. Besides during the experiment, the external conditions were changed: decreased temperature and increased load pressure. The experiment is based on the UPG-MG4-01. The paper presented the laboratory tests of heave and compressive strength of the frozen soils using applied geotechnical methods.
\end{abstract}

\section{INTRODUCTION}

The physical processes of the frost heave in soil have been studied since as early as $17^{\text {th }}$ century and progressed significantly up to present time due to the importance of the soil evaluation in engineering and construction. Frost heave reflects the destructive aspects of the frost action in freezing soil. It refers to the volume expansion during a process of soil freezing. In geomorphology, intensive frost heaving may create specific raised-soil landforms which have different geometries, e.g. circles, polygons, stripes. Unstable soil creates difficulties and danger in the construction of roads, buildings and highways.

The physical nature of the process of heave in soils is well described in a variety of the existing works (Taber, 1929, 1930; Ravaska and Vesala, 2000; Muller et al. 2008; Lein et al. 2019). If freezing of saturated soils results in no heaving, water is forced through the soil voids below the zone of freezing, compressing or expelling air. Heaving takes place when water is pulled through the soil to build up ice layers which grow in thickness. Heave also includes the development of ice lenses inside the columns of soil (Akagawa et al. 2006; Arenson et al. 2006). Since force is required to pull water through clay, the water is put under the high tension.

The first explanation of the frost heave was based on the capillary theory and was detailed constantly by numerous studies on geotechnical engineering (Penner, 1961; Penner \& Ueda, 1977; Rempel, 2012; Deprez et al. 2020). Heaving is limited by the tensile stress that is developing in water and by downward growth of the ice crystals in soil voids. Frost heave is usually caused by the water transfer and accumulation in soils, as described previously (Logan et al. 2020; Penner, 1960).

Another important feature of the heave in soils is that various types of soils demonstrate difference in the frost heave performance, compressibility and other soil properties. Frost heave of the ground soils may negatively influence the stability of buildings and constructions, because soil volume may increase during the freezing period. The variations in the heave of foundations could depend on various factors. These include among others soil type (silty, clay, fine-grained, etc.), hydration and moisture degree (Konrad, 1980).

The importance of the heave frost processes for the construction of road works and buildings explains numerous publication on soil heave and frost soils throughout the $20^{\text {th }}$ century (Puppala et al. 2004; Crowther, 2015; Konrad, 1994; Nagare, 2011; Li and Sun, 2008) and in recent research papers (Dahlin et al. 1999; Lindh and Hermansson, 2001; Lemenkov, 2018a, 2018e). Favourable conditions for the development of frost heave include the following factors: 1) frost-susceptible soil, 2) inflow of water below the water table; 3 ) local cold climate (freezing). Frost-susceptible soils are those vulnerable to the frost heave soil types that have pore sizes between the fine particles and surface area that enable capillary flow, e.g. silt and loam (Michalowski and Zhu, 2007; Zhang and Michalowski, 2014). 
The studies of the heave frost advanced rapidly since 1960s. This is caused by the rapid progress in geotechnical engineering methodology including updated technical devices and improved laboratory equipment for the soil testing. The progress in the geotechnical engineering continued further up to 1980s when the statistical data analysis facilitated existing research methods of data analysis (Jackson et al., 1966; Hagerty and Peck, 1971; Selvadurai and Shinde, 1993; Ketcham et al. 1997; Huang et al. 2004). These works presented a sound theoretical background for further development of the experiments on frost heave, based on the updated modern techniques and methods, asreflected in a series of the existing papers (Zhou et al. 2006; Darrow et al. 2008; Ferris, 2009; Wersäll and Massarsch, 2013; Zheng and Kanie, 2015; Shen et al. 2020; Chen et al. 2021). The methodological principles and approaches presented in these works were analysed and used in the present research with an application to the regional characteristics of the soil specimens used in the performed experiment.

Ground heave, caused by the impact of the hydrological and climatic external factors, e.g. in frost-susceptible regions, can lead to the significant vertical deformations in the foundation and frame of buildings, pavement and roads (Widianto et al. 2009; Chen et al. 2012; Zhang et al. 2018). In particular, frost heave in soils can lead to vertical deformation of the low-rise buildings. Since heaving of soils often corresponds to the nonlinear functions, the rise in building foundations also occur unevenly. This may lead to the fracture of buildings over time. Therefore, the hydrogeological risk analysis of the soil heaving is a necessary research step before the construction works. The uneven heave of clay and fine-grained soils causes uneven loads on the surfaces, building foundation and pavement (Long et al. 2018; Zhu et al. 2021). The reasons for the uneven soil heaving are different. For instance, soil heave in the southern regions can be caused by the heterogeneous geological formations under a shallow foundation, or by variations in local climate settings, e.g. uneven soil heating, differences in soil insulation, heated and unheated rooms on the same building foundation.

Current study presented a series of experiments performed in the soil laboratory (Fig. 1). The aim was to study physical and mechanical properties of soils. Technically, the work has been carried out according to the existing standards for frozen, freezing and thawing soils. This method determines soil temperature as a part of the engineering survey for designed and constructed structures. The research included the evaluation of the frost heave degree applied to the specimens of the finegrained loams and clay soils.

\section{DATA}

The hydrogeological, geological and technical properties of the tested soils have been determined by the enlarged aquifer of the groundwaters in the saturated loam soils below the water table. The thickness of the sediments is about 5-8 m, regional filtration coefficients vary within range of $0.3-0.14$ for clay soils and loams. Within the tested area, the aquifers are separated by the water-resistant clays with a thickness of 2-5 m.

Current paper is focused on the loam soil. The tested specimens of the loamy soil contain up to $30 \%$ clay and $70 \%$ sand. In dry conditions, loams are less hard than clay soils; in wet conditions loams have low ductility and stickiness. Loams are considered as heaving soils, as they contain over $15 \%$ of clay aggregate of the total mass in their structure.

Because loams in the study area are prone to freeze and subsidence, the engineering construction on this type of soil requires accurate evaluations of the physical and mechanical properties of soil. Soil subsidence, i.e. sinking or settling of the ground surface, results in sags (local geomorphic depressions) formed on the surface due to the variety of the environmental impact factors and trigger processes. Therefore, adjusting the hydrological regime in the area of soil subsidence presents a geotechnical challenge (López-Fernández et al. 2013).

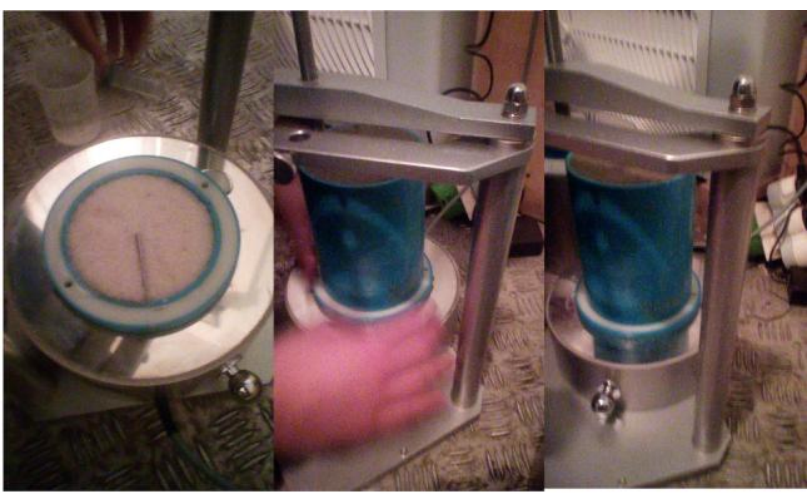

Figure 1. Illustrations of the experimental setup: a) Container fixed in a frame (left); Placing soil sample in the lower area (centre). Soil sample in cylinder (right)

Assessing the suitability of the region for possible construction of roads and buildings includes the analysis of possible changes in soils under various weather conditions and external pressure. The average depth of freezing in the studied region is $800 \mathrm{~mm}$, which varies depending on local hydrogeological and climatic conditions. Evaluating the soil column under the controlled laboratory settings can assist in understanding of the effects of various impact factors controlling the freezing of the active layer in the terrain. Therefore, testing freezing depth in soil specimens is necessary for hydrogeological analysis of the specific area selected as a potential place for planned construction of road. It should also be noted that soil hydration is an important factor increasing the degree of ground heaving.

Soil moisture profile fully saturated before freezing is especially important due to the seasonal river flooding, repetitive seasonal rains at the onset of spring period which significantly change the groundwater level (Wang et al. 2020). Soil moisture profile during the winter period controls the ice content in the surface layer of soils. As a result, seasonal freezing-thawing processes in soil may cause soil compaction and lead to the damages in the infrastructure (e.g. Lin et al. 2018; Wu et al. 2021).

\section{METHODS}

\subsection{Data pre-processing}

The study has been carried out based on the existing standard GOST $28622-2012$ by UPG-MG4.01/N Soil measuring device used to measure heave in soils. The work has been performed stepwise according to the methodology described below. The preliminary research step included sampling of the undisturbed 
soil, which was cut out of the soil monolith (a vertical slice of soil) by cutting ring method using the cylindrical shape. Afterwards, testing device (equipment UPG-MG4.01/N) has been installed and connected to the network. The program was installed using the "Instrument network" menu. Each sample was placed to the freezer thereafter. The water-thermal regime of the soil in laboratory conditions was provided by maintaining the two conditions:

- freezing of soil samples was performed only from the upper end of the cylinder;

- the temperature regime was set up on the lower and upper thermal plates as well as the surfaces of the soil samples.

The methodology of this work has followed the existing standards and knowledge on the evaluation of the frost heave in construction engineering works (Brown, 1965; Nishikawa and Sakuraba, 2002).

\subsection{Data processing}

At the initial stage of the experiment, soil specimens were installed. Sampling and preparation of the loamy soil specimens for testing were carried out according to the existing standards. The clip was placed together with a soil sample on a lower thermal plate (Fig. 1, in the centre). By this time, a thermal container with a lower thermal plate has been prepared for the experiment (Fig. 1).

\subsection{Soil sampling}

At the next step, a filter paper was placed on the bottom of the container, to prevent the infiltration of sand into the compartment with water. The capillary-porous fine sand was poured into the container up to the edges of the cylinder. The water was filled in to the cylinder using a medical syringe.

The lower end surface of the soil was tightly attached to the material. The cartridge inside the cylinder was lubricated by a thin layer of grease (petroleum jelly). Then the soil samples were placed into a holder consisting of five rings $30 \mathrm{~mm}$ high. The soil samples were previously prepared and stored in the rings using the standard method of soil compaction.

\subsection{Instalment of thermal plates}

At the next stage, after a thermal insulating case was installed on the top of the cylinder containing soil, the upper thermal plate has been installed on the ground. The measurement device containing soil sample has been placed on the base of the frame (Fig. 1). The upper and lower thermal plates were connected to the joints of the control unit device according to the numbering of the thermal containers. Afterwards, the freezing sensor has been connected. At the next step, the temperature and pressure parameters were set up in the settings mode of the device.

\subsection{Fixing temperature}

At the same time, following parameters were installed in the upper line of the display: Ta is the air temperature in the refrigerator; current time is the time since the start of the experiment. The second line in the first column displays the series number and number of current measurement. The other columns included the numbers of thermal containers. The table also included the following parameters: temperature of the upper thermal plate Tut, ${ }^{\circ} \mathrm{C}$, temperature of lower thermal plate $\mathrm{Tlt},{ }^{\circ} \mathrm{C}$, temperature of the lower end of the sample Tcont, ${ }^{\circ} \mathrm{C}$.

The air temperature in the refrigerator was fixed as a constant to ensure the average temperature on the upper thermal plates, which was equal to $1 \pm 0.5^{\circ} \mathrm{C}$. This ensured that soils samples could be subjected to bidirectional, one-dimensional freezing. The time of the temperature stabilization reached 7 hours. Such temperature conditions were maintained for 24 hours. Afterwards, the temperature of the upper thermal plates automatically decreased to the temperature Tut, ${ }^{\circ} \mathrm{C}=15.5^{\circ} \mathrm{C}$ set in the "Settings" mode.

\subsection{Determining frost heaving}

At the final step, frost heaving of the soil samples was determined. Frost heave of the samples is expressed as the volumetric strain, which leads to the increase of volume due to the crystallization of pores and migrating water with the formation of crystals and ice lenses. Soil deformations caused by the frost heaving were measured with an accuracy of 0.01 $\mathrm{mm}$. The total experiment time for these soil samples was 57 hours. The test was completed by the signal of the indicator warning activation of the freezing sensor. Measured values of the Tut, ${ }^{\circ} \mathrm{C}$, Tlt, ${ }^{\circ} \mathrm{C}$, Tcont, ${ }^{\circ} \mathrm{C}, \mathrm{h}$ and $\mathrm{P}$ were automatically recorded in real time during the test and archived as files.

\section{RESULTS}

This paper presents the results of the experimental testing of the temperature regime of the frozen loamy soils. The results of laboratory tests of soils are shown in Table 1 and Figures 2-7. The tested soil samples experience seasonal freezing and thawing. The experiments were performed using standard method of assessment of soil frost heave using device UPGMG4.01/N, at the temperatures from $-4.6^{\circ} \mathrm{C}$ to $-4.1^{\circ} \mathrm{C}$. The displacement of the soil samples at temperature of $-4.3^{\circ} \mathrm{C}$ reached $0.91 \mathrm{~mm}$.

\begin{tabular}{|l|l|l|l|l|l|l|}
\hline Series & No & $\begin{array}{c}\mathbf{T} \text { upper, } \\
{ }^{\circ} \mathbf{C}\end{array}$ & $\begin{array}{c}\mathbf{T}, \text { lower, } \\
{ }^{\circ} \mathbf{C}\end{array}$ & $\begin{array}{c}\mathbf{T} \text { control, } \\
{ }^{\circ} \mathbf{C}\end{array}$ & $\begin{array}{c}\text { Pressure, } \\
\mathbf{M P a}\end{array}$ & $\begin{array}{c}\text { Hf, Displacement, } \\
\mathbf{m m}\end{array}$ \\
\hline 7 & 15 & $-4,3$ & 0,9 & 0,4 & 0,001 & 1,21 \\
\hline 7 & 16 & $-3,9$ & 0,9 & 0,4 & 0,001 & 1,30 \\
\hline 7 & 17 & $-4,2$ & 0,9 & 0,4 & 0,001 & 1,41 \\
\hline 7 & 18 & $-4,3$ & 0,9 & 0,3 & 0,001 & 1,53 \\
\hline 7 & 19 & $-4,3$ & 1,0 & 0,4 & 0,001 & 1,61 \\
\hline 7 & 20 & $-4,2$ & 0,9 & 0,3 & 0,001 & 1,69 \\
\hline 7 & 21 & $-4,1$ & 1,0 & 0,3 & 0,001 & 1,79 \\
\hline 7 & 22 & $-4,2$ & 0,9 & 0,2 & 0,002 & 1,89 \\
\hline 7 & 23 & $-4,1$ & 0,9 & 0,4 & 0,002 & 1,99 \\
\hline 7 & 24 & $-4,0$ & 0,9 & 0,2 & 0,002 & 2,09 \\
\hline 7 & 25 & $-4,1$ & 0,9 & 0,2 & 0,002 & 2,21 \\
\hline 7 & 26 & $-4,2$ & 0,9 & 0,2 & 0,002 & 2,34 \\
\hline 7 & 27 & $-4,2$ & 1,0 & 0,0 & 0,002 & 2,41 \\
\hline
\end{tabular}

Table 1. Example of the series of measurements

The experimental tests in all five thermal containers were finished by freezing sensor indicator. Data obtained during the experiment were transfer to a PC via USB from the UPG- 
MG4.01/N device and archived to a file using the software for transmitting the datasets directly from the UPG-MG4.01/N "Grunt" device.

The technical part of the experiment has been performed using the UPG-MG4.01/N thermometric equipment. The temperature of soils was measured by analysing the temperature of the upper and lower thermal plates in real time regime. The experimental method was based on the analysis of the temperature regime of given soils samples prepared and tested for engineering and construction surveys in natural and disturbed conditions (with and without external temperature exposure). Methodologically, the use of the UPG-MG4.01 demonstrated high effectiveness in soil sampling and estimating the frost heave.
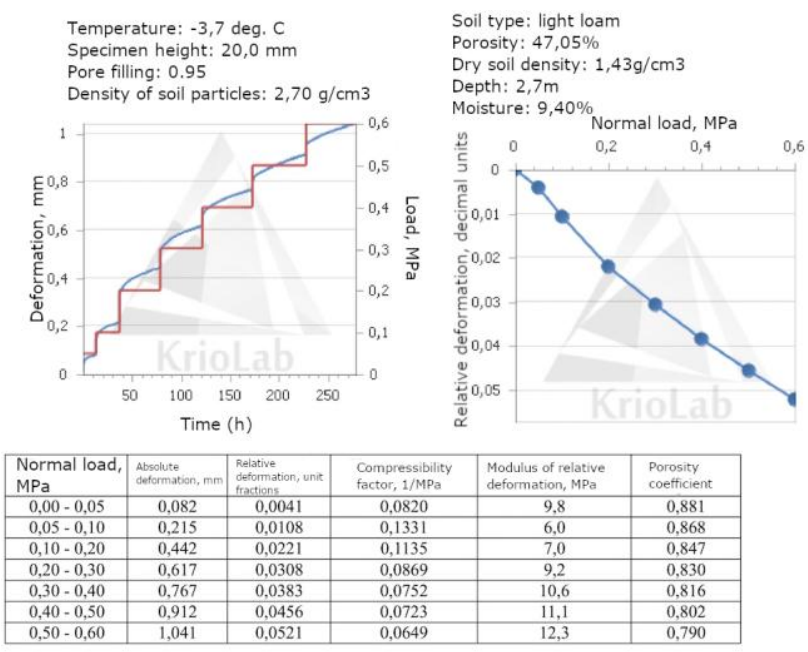

Figure 2. Results of the experimental testing of the compressive strength in soil specimens with porosity $47.05 \%$.
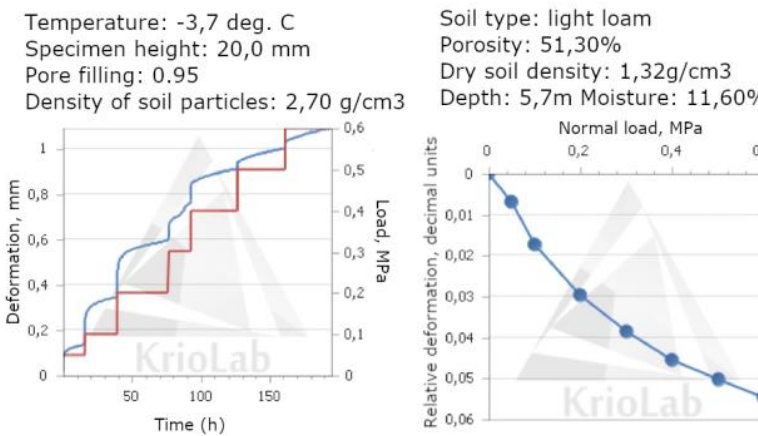

Depth: $5,7 \mathrm{~m}$ Moisture: $11,60 \%$

Density of soil particles: $2,70 \mathrm{~g} / \mathrm{cm}$
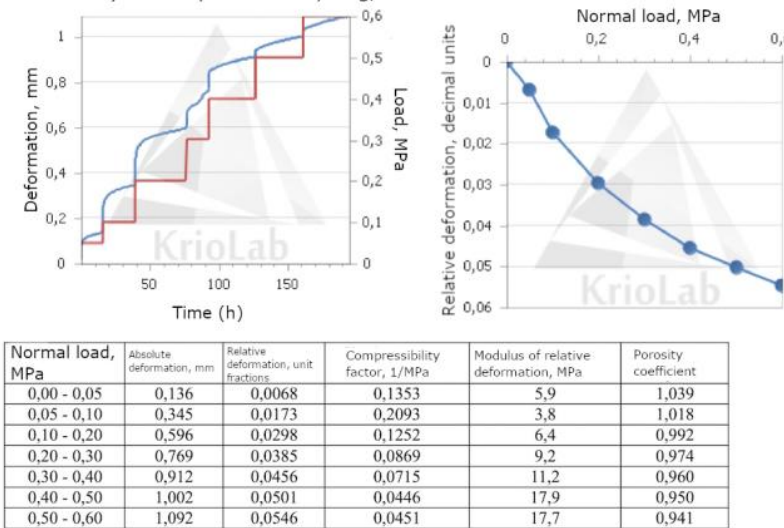

Figure 3. Results of the experimental testing of the compressive strength in soil specimens with porosity $51.30 \%$

First, this device provides optimal freezing process of the soil samples from the upper thermal plate. Second, fixed temperature regime has been set and maintained for the lower and upper thermal plates during the whole experiment continuously, which ensured the correctness and objectiveness of the experiment. Third, a continuous flow of water to the freezing line of the soil was ensured during the freezing of the soil specimens.
The obtained data shown that decrease of the temperature to $4.6^{\circ} \mathrm{C}$ has a significant effect on the frost heaving of the refractory and loam soils of a given study area. This effect can be seen as an increase in the short-term volume of the soil samples with the increase in their hydration saturation under the external temperature effects. On the contrary, the decrease is observed in their volume during thawing. According to the results of the experiments, the calculated degree of heaving in the soil specimens is $0.91 \mathrm{~mm}$ at the temperature of $-4.3^{\circ} \mathrm{C} \mathrm{T}$.
Temperature: $-3,7 \mathrm{deg} . \mathrm{C}$
Specimen height: $20,0 \mathrm{~mm}$
Pore filling: 0.98

Density of soil particles: $2,69 \mathrm{~g} / \mathrm{cm} 3$

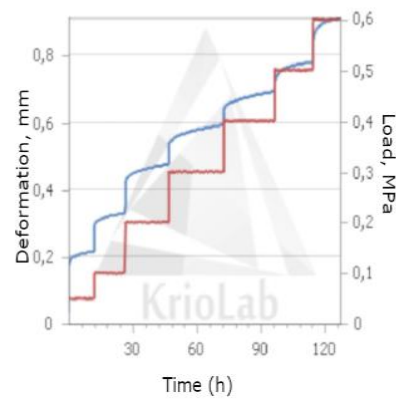

Soil type: light loam

Porosity: $59,85 \%$

Dry soil density: $1,08 \mathrm{~g} / \mathrm{cm}^{3}$

Depth: $1,9 \mathrm{~m}$ Moisture: $4,90 \%$

\begin{tabular}{|c|c|c|c|c|c|}
\hline $\begin{array}{l}\text { Normal load, } \\
\mathrm{MPa}\end{array}$ & $\begin{array}{l}\text { Absolute } \\
\text { defarmation, mmm }\end{array}$ & $\begin{array}{l}\text { Relative } \\
\text { defermation, unit } \\
\text { fractions }\end{array}$ & $\begin{array}{l}\text { Compressibility } \\
\text { factor, 1/MPa }\end{array}$ & $\begin{array}{l}\text { Modulus of relative } \\
\text { defarmation, MPa }\end{array}$ & $\begin{array}{l}\text { Porosity } \\
\text { coefficient }\end{array}$ \\
\hline $0,00-0,05$ & 0,214 & 0,0107 & 0,2139 & 3,7 & 1,464 \\
\hline $0,05-0,10$ & 0,329 & 0,0165 & 0,1152 & 6,9 & 1,450 \\
\hline $0,10-0,20$ & 0,475 & 0,0238 & 0,0732 & 10,9 & 1,432 \\
\hline $0,20-0,30$ & 0,593 & 0,0296 & 0,0586 & 13,7 & 1,417 \\
\hline $0,30-0,40$ & 0,692 & 0,0346 & 0,0498 & 16,1 & 1,405 \\
\hline $0,40-0,50$ & 0,780 & 0,0390 & 0,0439 & 18,2 & 1,394 \\
\hline $0,50-0,60$ & 0,910 & 0,0455 & 0,0648 & 12,3 & 1,377 \\
\hline
\end{tabular}

Figure 4. Results of the experimental testing of the compressive strength in soil specimens with porosity $59.85 \%$
Temperature: $-3,7$ deg. C Specimen height: $20,0 \mathrm{~mm}$

Pore filling: 1.06

Density of soil particles: $2,69 \mathrm{~g} / \mathrm{cm} 3$

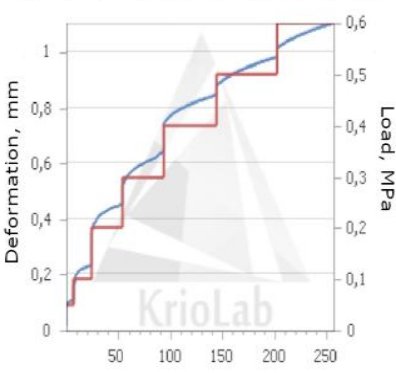

Time (h)
Soil type: light loam Porosity: $69,28 \%$

Depth: 5,9m Moisture: $9,00 \%$

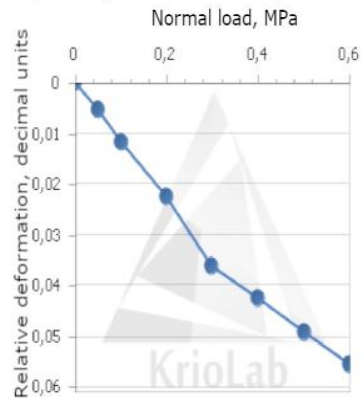

Dry soil density: $0,83 \mathrm{~g} / \mathrm{cm} 3$

\begin{tabular}{|c|c|c|c|c|c|}
\hline $\begin{array}{l}\text { Normal load, } \\
\text { MPa }\end{array}$ & $\begin{array}{l}\text { absolute } \\
\text { deformation, mm } m\end{array}$ & $\begin{array}{l}\text { Relative } \\
\text { deformation, unit } \\
\text { farctions }\end{array}$ & $\begin{array}{l}\text { Compressibility } \\
\text { factor, } 1 / \text { MPa }\end{array}$ & $\begin{array}{l}\text { Modulus of relative } \\
\text { deformation, MPa }\end{array}$ & $\begin{array}{l}\text { Porosity } \\
\text { coefficient }\end{array}$ \\
\hline $0,00-0,05$ & 0,110 & 0,0055 & 0,1090 & 7,3 & 2,237 \\
\hline $0,05-0,10$ & 0,233 & 0,0116 & 0,1223 & 6,5 & 2,217 \\
\hline $0,10-0,20$ & 0,453 & 0,0227 & 0,1107 & 7,2 & 2,181 \\
\hline $0,20-0,30$ & 0,722 & 0,0361 & 0,1349 & 5,9 & 2,137 \\
\hline $0,30-0,40$ & 0,847 & 0,0423 & 0,0621 & 12,9 & 2,117 \\
\hline $0,40-0,50$ & 0,984 & 0,0492 & 0,0681 & 11,7 & 2,095 \\
\hline $0,50-0,60$ & 1,106 & 0,0553 & 0,0614 & 13,0 & 2,075 \\
\hline
\end{tabular}

Figure 5. Results of the experimental testing of the compressive strength in soil specimens with porosity $69.28 \%$ 


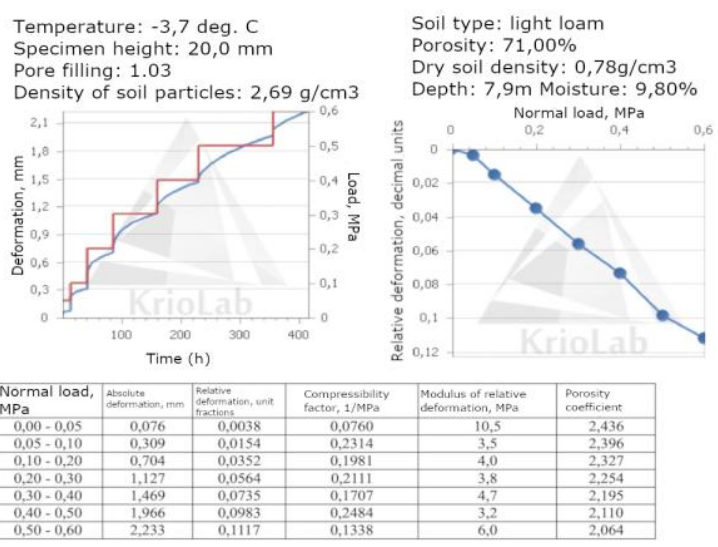

Figure 6. Results of the experimental testing of the compressive strength in the soil specimens with porosity $71.00 \%$

The experimental part of this work includes the quantitative estimation of the frost heaving of the selected soil specimens. The functionality of the UPG-MG4.01 device enabled to measure the relative deformation of the frost heaving $\varepsilon_{\mathrm{fh}}$.

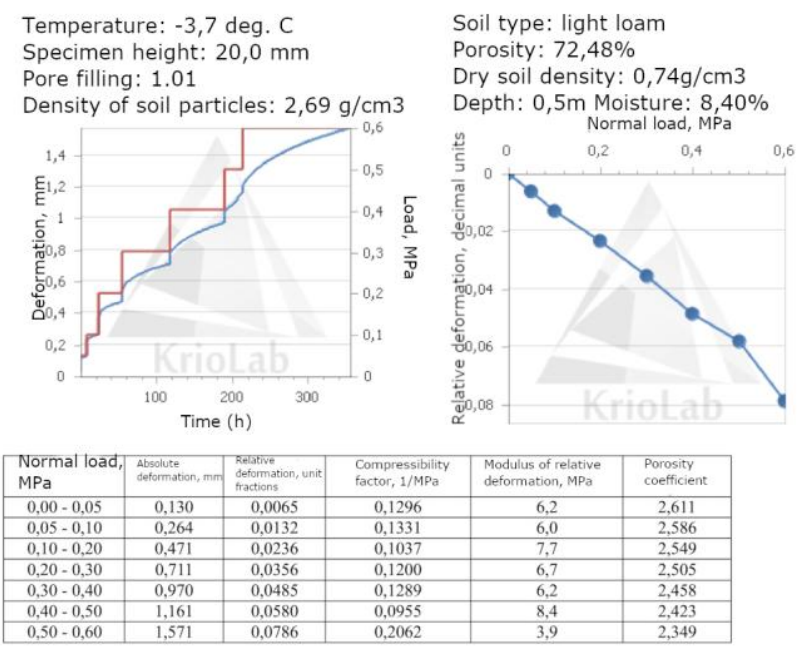

Figure 7. Results of the experimental testing of the compressive strength in the soil specimens with porosity $72.48 \%$

\section{DISCUSSION}

The novelty of this work consists in the application of the advanced geotechnical methods for evaluating of heave in the frozen soils. The heave testing has been performed using the special device by a series of the laboratory tests. The results demonstrated that heave, temperature and water intake in the specimens of the frozen soil demonstrate correlation and effects during compression test experiments. The results support the theoretical descriptions of the soil performance (Jame, 1978; Guymon et al. 1993; Hayashi et al. 2007). This study presents the foundation for further testing of the frozen soil's heave.

Various experimental methods have been used for the measurements of the frost heave and freeze durability of soils (McCabe and Kettle, 1995; Rempel et al. 2004, Lemenkov, 2018c; Penner, 1959; Dirksen, 1964). These studies were mostly developed as applications and case studies for natural soils with few examples for the stabilized soils. Soil heave may vary depending on the soil type and chemical content (Lemenkov, 2018d).
Soil samples stabilized with a lime-slag binder and samples stabilized with a cement binder showed only a very small frost heave. The fine-grained soils are often regarded as problematic soils in earthworks due to the high water sensitivity and frost heave. Soil treated with a low amount of lime could become more frost-susceptible than the untreated soil specimens (Lindh, 2004).

Rapid progress in computerization and the onset of the automation in data analysis in geosciences enabled the development of the methods of data analysis (Schenke and Lemenkova, 2008; Klaučo et al. 2013; Houston and Houston, 2017; Lemenkov, 2018b; Xie et al. 2018; Lemenkova, 2019, 2020; Lemenkov and Lemenkova, 2021a). Regarding the soil science and geotechnical measurements of frost heave, the active use of the computed-assisted data processing and soil sampling improves the quality and speed of data analysis and should be recommended in similar studies.

\section{CONCLUSION}

The actuality of the work is caused by the need for the precise measurements of the soil properties. Testing soils aims to estimate their suitability for the construction works. The frost heave of soils, i.e. their ability to retain water in their volume is one of the most significant negative soil characteristics for building constructions. The hydrated saturated loamy soils can be prone to the frost heaving, which causes difficulties in building constructions and planning.

Measuring quality and suitability of soils in specific areas is necessary before construction works, which is crucial for the regions with rapid development. Hence, this work is a contribution to the development and improvement of the technical methods aimed for accurate assessment of the heaving of refractory and loam soils based on the use of the UPGMG4.01/N equipment. The described workflow can be used as an example in similar experiments on the heave soils testing. The presented experiments are aimed to contribute to a better understanding of the frozen soils heaving generated from the field investigations in frozen soils by the UPG-MG4.01/N .

The assessment of the physical and mechanical properties of soil is important, because it enables to estimate the load on the structure and evaluate how the loads are being transmitted to the earth with possible consequences on a structure of building (Duncan, 1992). Errors in the hydrogeological calculations or the incorrect assessment of the compression strength of soil can result in cracked or rickety buildings. The correction of such errors is often very costly in the industry. Thus, the quality of the buildings's structure, the exploitation reliability and possible risks, directly depend on the reliable and accurate assessment of the suitability of soil for the construction works. This work contributed to the development of testing methods by a case study of the frozen soils evaluated for compressive strength.

\section{References}

Akagawa, S., Satoh, M., Kanie, S., Mikami, T., 2006. Effect of Tensile Strength on Ice Lens Initiation Temperature. In: $13^{\text {th }}$ International Conference on Cold Regions Engineering, July 
23-26, 2006, Orono, Maine, United States, pp. 1-12. https://doi.org/10.1061/40836(210)43.

Arenson, L. U., Xia, D., Sego, D. C., Biggar, K. W. 2006. Change in Ice Lens Formation for Saline and Non-Saline Devon Silt as a Function of Temperature and Pressure. In: $13^{\text {th }}$ International Conference on Cold Regions Engineering. July 23-26, 2006, Orono, Maine, United States. https://doi.org/10.1061/9780784482469.049.

Brown, W. G., 1965. Frost Heave in Ice Rinks and Cold Storage Buildings, CBD-61, Research Council Canada. https://doi.org/10.4224/40000839.

Chen, D. H., Scullion, T., Hong, F., Lee, J., 2012. Pavement Swelling and Heaving at State Highway 6. Journal of Performance of Constructed Facilities, 26(3), pp. 335-344. https://doi.org/10.1061/(ASCE)CF.1943-5509.0000237.

Chen, J., Li, A., Bao, C., Dai, Y., Liu, M., Lin, Z., Niu, F., Zhou, T., 2021. A deep learning forecasting method for frost heave deformation of high-speed railway subgrade. Cold Regions Science and Technology, 185, pp. 103265. https://doi.org/10.1016/j.coldregions.2021.103265.

Crowther, G. S., 2015. Lateral Pile Analysis Frozen Soil Strength Criteria. Journal of Cold Regions Engineering, 29(2): 04014011. 5495.0000078 https://doi.org/10.1061/(ASCE)CR.1943-

Dahlin T., Svensson M., Lindh P. DC Resistivity and SASW for Validation of Efficiency in Soil Stabilisation Prior to Road Construction. In Procs. EEGS'99, 1999.

Darrow, M. M., Huang, S. L., Shur, Y., Akagawa, S., 2008. Improvements in Frost Heave Laboratory Testing of FineGrained Soils. Journal of Cold Regions Engineering, 22(3), 6578. https://doi.org/10.1061/(ASCE)0887-381X(2008)22:3(65).

Deprez, M., De Kock, T., De Schutter, G., Cnudde, V., 2020. A review on freeze-thaw action and weathering of rocks. EarthScience Reviews 203, pp. 103143 https://doi.org/10.1016/j.earscirev.2020.103143.

Dirksen, C., 1964. Water Movement and Frost Heaving in Unsaturated Soil without an External Source of Water, Ph. D. thesis, Cornell University, United States - New York, 152 pp.

Duncan C.I. (1992) Physical Properties of Soils. In: Soils and Foundations for Architects and Engineers. Springer, Boston, MA. https://doi.org/10.1007/978-1-4757-6545-8_2.

Ferris, G., 2009. Differential Frost Heave at Pipeline-Road Crossings. In: $14^{\text {th }}$ Conference on Cold Regions Engineering, August 31 - September 2, 2009, Duluth, Minnesota, United States, pp. 68-78. https://doi.org/10.1061/41072(359)9.

Guymon, G. L., Berg, R. L., Hromadka, T. V., 1993. Mathematical Model of Frost Heave and Thaw Settlement in Pavements, US Army Corps Cold Regions Research \& Engineering Laboratory, $130 \mathrm{pp}$.

Hagerty, D. J., Peck, R. B., 1971. Heave and Lateral Movements due to Pile Driving. ASCE Soil Mechanics and Foundation Division Journal 97(11), pp. 1513-1532. https://doi.org/10.1061/JSFEAQ.0001700.

Hayashi, M., Goeller, N., Quinton, W. L., Wright, N., 2007. A simple heat-conduction method for simulating the frost-table depth in hydrological models. Hydrological Processes, 21, pp. 2610-2622. https://doi.org/10.1002/hyp.6792.

Houston, S. L., Houston, W. N., 2017. Suction-Oedometer Method for Computation of Heave and Remaining Heave. In: Second Pan-American Conference on Unsaturated Soils November 12-15, 2017, Dallas, Texas, United States. pp. 93116. https://doi.org/10.1061/9780784481677.005.
Huang, S. L., Bray, M. T., Akagawa, S., Fukuda, M., 2004 Field Investigation of Soil Heave by a Large Diameter Chilled Gas Pipeline Experiment, Fairbanks, Alaska. Journal of Cold Regions Engineering, 18(1), 2-34. https://doi.org/10.1061/(ASCE)0887-381X(2004)18:1(2).

Jackson, K. A., Uhlmann, D. R., Chalmers, B. 1966. Frost Heave in Soils. Journal of Applied Physics 37(2), pp. 848 852. https://doi.org/10.1063/1.1708270.

Jame, Y.: Heat and Mass Transfer in Freezing Unsaturated Soil, $\mathrm{Ph}$. D. thesis, The University of Saskatchewan, Canada, 212 pp., 1978.

Ketcham, S. A., Black, P. B., Pretto, R., 1997. Frost Heave Loading of Constrained Footing by Centrifuge Modeling. Journal of Geotechnical and Geoenvironmental Engineering, 123(9), pp. 874-880. https://doi.org/10.1061/(ASCE)10900241(1997)123:9(874).

Klaučo, M., Gregorová, B., Stankov, U., Marković, V., Lemenkova, P., 2013. Determination of ecological significance based on geostatistical assessment: a case study from the Slovak Natura 2000 protected area. Open Geosciences, 5(1), pp. 28-42. https://doi.org/10.2478/s13533-012-0120-0.

Konrad, J. M., 1980. Frost heave mechanics. Ph. D. thesis. Canada, Department of Civil Engineering, University of Alberta, Edmonton, Canada, 472 pp. https://doi.org/10.7939/R3WP9TH3B.

Konrad, J. M. 1994. Sixteenth Canadian geotechnical colloquium: frost heave in soils: concepts and engineering, Canadian Geotechnical Journal, 31(2), pp. 223-245. https://doi.org/10.1139/t94-028.

Lein, W. A., Slone, S. M., Smith, C. E., Bernier, A. P., 2019. Frost Depth Penetration and Frost Heave in Frost Susceptible Soils. In: International Airfield and Highway Pavements Conference: Testing and Characterization of Pavement Materials, July 21-24, 2019, Chicago, Illinois, U.S., pp. 493503. https://doi.org/10.1061/9780784482469.049.

Lemenkov, V. A., 2018a. Determination of correlation in deformation, strength and viscosity of the frozen soils through external pressure by uniaxial compression. In: Current Trends and Innovations in Science and Industry, Mezhdurechensk, Russia, 24-25 April 2018. pp. 64-65. https://doi.org/10.5281/zenodo.3832280.

Lemenkov, V. A. 2018b. Variations in porosity and deformation in dehydrated loam samples. In: Development Strategy of the Geological Exploration of the Subsoils: Present and Future, Moscow, Russia, 2018, 2, pp. 256-257. https://doi.org/10.5281/zenodo.3832310.

Lemenkov, V. A., 2018c. Perspective methods for determining deformation of the frozen dispersed soils under external loads. In: Problems of the Arctic Region, Murmansk, Russia, pp. 2930. https://doi.org/10.5281/zenodo.3832332.

Lemenkov, V. A. 2018d. Analysis of the Effects of the Mineral Soil Composition on the Cohesion Between its Structural Elements. In: Modern Solutions to Scientific and Industrial Problems in Chemistry and Petrochemistry, Kazan, Russia, 2018. pp. 617-625. https://doi.org/10.5281/zenodo.3832326.

Lemenkov, V. A. 2018e. Deformation properties of the clay soil heave with a case study of sandy loam and clay by compression tests. In: Development Strategy of the Geological Exploration of the Subsoils: Present and Future, Moscow, Russia, 2, pp. 258-259. https://doi.org/10.5281/zenodo.3832304.

Lemenkov, V., Lemenkova, P., 2021a. Using TeX Markup Language for 3D and 2D Geological Plotting. Foundations of Computing and Decision Sciences 46(3), pp. 43-69. https://doi.org/10.2478/fcds-2021-0004. 
Lemenkov, V., Lemenkova, P., 2021b. Measuring Equivalent Cohesion Ceq of the Frozen Soils by Compression Strength Using Kriolab Equipment. Civil and Environmental Engineering Reports, 31(2), pp. 63-84. https://doi.org/10.2478/ceer-2021-0020.

Lemenkova P., 2019. Statistical Analysis of the Mariana Trench Geomorphology Using R Programming Language. Geodesy and Cartography, 45, $\quad$ pp. 57-84. https://doi.org/10.3846/gac.2019.3785

Lemenkova, P., 2020. Using GMT for 2D and 3D Modeling of the Ryukyu Trench Topography, Pacific Ocean. Miscellanea Geographica, 25(3), pp. 1-13. https://doi.org/10.2478/mgrsd2020-0038

Li, Q., Sun, S. F. 2008. Development of the universal and simplified soil model coupling heat and water transport. Science in China Series D Earth Sciences, 51(1), pp. 88-102. https://doi.org/10.1007/s11430-007-0153-2.

Lin, Z., Niu, F., Li, X., Li, A., Liu, M., Luo, J., Shao, Z., 2018. Characteristics and controlling factors of frost heave in highspeed railway subgrade, Northwest China. Cold Regions Science and Technology, 153, 33-44. https://doi.org/10.1016/j.coldregions.2018.05.001

Lindh, P., Hermansson, Å., 2001. Test method to evaluate frost performance and frost heave of stabilised soil. International symposium on subgrade stabilisation and in situ pavement recycling using cement, Salamanca, October 2001. pp 241-754

Lindh P., 2004. Compaction- and strength properti stabilised and unstabilised fine- grained tills. Lund Unive Lund, Sweden. Doctoral Thesis. https://doi.org/10.13140/RG.2.1.1313.6481

Logan, T., Bilodeau, J.-P., Henry, K., 2020. Frost Action and Climate Change. Chapter 5. In: Shoop, S. A. (Ed.). Frost Action in Soils: Fundamentals and Mitigation in a Changing Climate. Publisher: American Society of Civil Engineers. https://doi.org/10.1061/9780784415085.

Long, X., Cen, G., Cai, L., Chen, Y. 2018. Model experiment of uneven frost heave of airport pavement structure on coarsegrained soils foundation. Construction and Building Materials, $\begin{array}{llll}188, & 372 & - & 380\end{array}$ https://doi.org/10.1016/j.conbuildmat.2018.08.100

López-Fernández, C., Prieto, D.A., Fernández-Viejo, G., Pando, L., Castells Fernández, E., 2013. Surface Subsidence Induced by Groundwater Drainage Tunneling in Granite Residual Soils (Burata Railway Tunnel, Spain). Journal of Geotechnical and Geoenvironmental Engineering, 139(5), 821-824. https://doi.org/10.1061/(ASCE)GT.1943-5606.0000805.

McCabe, E.Y. and Kettle, R.J., 1995. Soil Freezing Response: Influence of Test Conditions. Geotechnical Testing Journal, 8(2), pp. 49 - 58. https://doi.org/10.1520/GTJ10510J

Michalowski, R. L., Zhu, M., 2007. Modeling Heaving in FrostSusceptible Soils. Computer Applications In Geotechnical Engineering, Geotechnical Special Publication. Geo-Denver 2007 February 18-21, 2007, Denver, Colorado, United States. pp. 1-10. https://doi.org/10.1061/40901(220)18.

Muller, S. W., French, H., Nelson, F., 2008. Frozen in Time: Permafrost and Engineering Problems. American Society of Civil Engineers. https://doi.org/10.1061/9780784409893.

Nagare, R. M., 2011. Coupled Heat and Water Transport in Frozen Organic Soils. Ph. D. thesis, The University of Western Ontario, London, Canada, 191 pp. https://ir.lib.uwo.ca/etd/158.

Nishikawa, J., Sakuraba, M., 2002. Frost Heave Experiment in Open Pit. In: $11^{\text {th }}$ International Conference on Cold Regions Engineering, May 20-22, 2002, Anchorage, Alaska, United States, pp. 675-682. https://doi.org/10.1061/40621(254)58.
Penner. E., 1959. The mechanism of frost heaving in soils. Highway Research Board Bulletin, 221, p. 1-22.

Penner, E., 1960. The importance of freezing rate in frost action in soil. Proceedings-American society for testing and materials, 60, pp. 1151-1165

Penner, E, 1961. Alternative freezing and thawing not a requirement for frost heaving in soils. Canadian Journal of Soil Science, 16(1), pp. 160 - 163 https://doi.org/10.4141/cjss61-021.

Penner, E, Ueda, T., 1977. The dependence of frost heaving on load application-preliminary results. In: Proceedings of the International Symposium on Frost Action in Soils, 1, pp. 137143, Luleå University of Technology, Lulea, Sweden.

Puppala, A. J., Griffin, J. A., Hoyos, L. R., Chomtid, S., 2004 Studies on Sulfate-Resistant Cement Stabilization Methods to Address Sulfate-Induced Soil Heave. Journal of Geotechnical and Geoenvironmental Engineering, 130(4), 391-402. https://doi.org/10.1061/(ASCE)1090-0241(2004)130:4(391).

Ravaska, O., Vesala, E., 2000. A permafrost foundation analysis. In: Ground Freezing 2000 - Frost Action in Soils. $1^{\text {st }}$ Ed. https://doi.org/10.1201/9781003078654-48

Rempel, A. W., Wettlaufer, J. S., Worster, M. G., 2004 Premelting dynamics in a continuum model of frost heave. Journal of Fluid Mechanics, 498, pp. 227-244. https://doi.org/10.1017/S0022112003006761.

Rempel, A.W., 2012. Hydromechanical Processes in Freezing Soils. Vadose Zone Journal, 11, vzj2012.0045. https://doi.org/10.2136/vzj2012.0045.

Shen, Y., Liu, X., Zuo, R., Tang, T., Tian, Y., Wang, Y., 2020. Effect of frost heave on a silt column filled with rubber-asphaltfiber. Cold Regions Science and Technology, 174, 102991. https://doi.org/10.1016/j.coldregions.2020.102991.

Schenke, H. W., Lemenkova, P., 2008. Zur Frage der Meeresboden-Kartographie: Die Nutzung von AutoTrace Digitizer für die Vektorisierung der Bathymetrischen Daten in der Petschora-See. Hydrographische Nachrichten, 81, pp. 1621. https://doi.org/10.6084/m9.figshare.7435538.

Selvadurai, A. P. S., Shinde, S. B., 1993. Frost Heave Induced Mechanics of Buried Pipelines. Journal of Geotechnical Engineering, 119(12), pp. 1929-1951. https://doi.org/10.1061/(ASCE)0733-9410(1993)119:12(1929).

Taber, S., 1929. Frost heaving. Journal of Geology, 37(5), pp. 428 - 461. https://doi.org/10.1086/623637.

Taber, S., 1930. The mechanics of frost heaving. Journal of Geology, 38(4), pp. 303-317. https://doi.org/10.1086/623720.

Wang, X., Wang, C., Wang, X., Huo, Z., 2020. Response of soil compaction to the seasonal freezing-thawing process and the key controlling factors. CATENA, 184, 104247. https://doi.org/10.1016/j.catena.2019.104247.

Wersäll, C., Massarsch, K. R., 2013. Soil heave due to pile driving in clay. Sound Geotechnical Research to Practice, Geotechnical Special Publication (GSP 230) Honoring Robert D. Holtz, Edited by Armin W. Stuedlein, Ph. D., P.E., and Barry R. Christopher, Ph.D., P.E., ASCE, pp. 481 - 499. https://doi.org/10.1061/9780784412770.032.

Widianto, Heilenman, G., Owen, J., Fente, J., 2009. Foundation Design for Frost Heave. In: $14^{\text {th }}$ Conference on Cold Regions Engineering. August 31-September 2, 2009. Duluth, Minnesota,

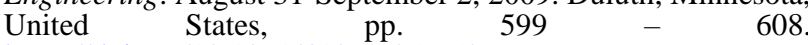
https://doi.org/10.1061/41072(359)58.

Wu, Y., Zhai, E., Zhang, X., Wang, G., Lu, Y., 2021. A study on frost heave and thaw settlement of soil subjected to cyclic freeze-thaw conditions based on hydro-thermal-mechanical 
coupling analysis. Cold Regions Science and Technology, 188, 103296. https://doi.org/10.1016/j.coldregions.2021.103296.

Xie, H., Shanmugam, A. K., Issa, R. R. A., 2018. Big Data Analysis for Monitoring of Kick Formation in Complex Underwater Drilling Projects. Journal of Computing in Civil $\begin{array}{lll}\text { Engineering, } & 32(5), & \text { pp. }\end{array}$ https://doi.org/10.1061/(ASCE)CP.1943-5487.0000773.

Zhang, Y., Michalowski, R. L., 2014. Thermal-HydroMechanical Modeling of Frost Action in Frost-Susceptible Soils. Geotechnical Special Publication, Geo-Shanghai 2014 May 26-28, 2014, Shanghai, China, pp. 735-744. https://doi.org/10.1061/9780784413388.077.

Zhang, Y., White, D. J., Vennapusa, P. K. R., Johnson, A. E., Prokudin, M. M. 2018. Investigating Frost Heave Deterioration at Pavement Joint Locations. Journal of Performance of Constructed Facilities, 32(2), 04018001. https://doi.org/10.1061/(ASCE)CF.1943-5509.0001143.

Zheng, H., Kanie, S., 2015. Combined Thermal-HydraulicMechanical Frost Heave Model Based on Takashi's Equation. Journal of Cold Regions Engineering, 29(4), 04014019. https://doi.org/10.1061/(ASCE)CR.1943-5495.0000089.

Zhou, F., Zai, J., Mei, G., Zhou, G., 2006. Analysis of Soil Heave Due to Pile-Sinking in Soft Clay. GeoShanghai International Conference, June 6-8, 2006, Shanghai, China, pp. 271-276. https://doi.org/10.1061/40865(197)35

Zhu, Y., Li, Y., Hao, Z., Luo, L., Luo, J., Wang, L., 2021. An analytical solution for the frost heaving force and displacement of a noncircular tunnel. Computers and Geotechnics, 133 , 104022. https://doi.org/10.1016/j.compgeo.2021.104022. 